\title{
lodine Deficiency Disorder and Its Association with Academic Performance Among Children in Jimma Town, Southwestern Ethiopia
}

\author{
Yinebeb Mezgebu ${ }^{1,}$, , Andualem Mossie ${ }^{2}$, PN Rajesh ${ }^{3}$, Hailie Fentahun $^{1}$ \\ ${ }^{1}$ Department of Medical Physiology, College of Medicine \& Health Sciences, Bahir Dar University, Bahir Dar, Ethiopia \\ ${ }^{2}$ Department of Biomedical Sciences (Physiology), College of Public Health and Medical Sciences, Jimma University, Jimma, Ethiopia \\ ${ }^{3}$ Department of Biomedical Sciences (Biochemistry), College of Health Sciences, Debre Tabor University, Debre Tabor, Ethiopia
}

\section{Email address:}

yinexju@gmail.com (Y. Mezgebu)

${ }^{*}$ Corresponding author

\section{To cite this article:}

Yinebeb Mezgebu, Andualem Mossie, PN Rajesh, Hailie Fentahun. Iodine Deficiency Disorder and Its Association with Academic Performance Among Children in Jimma Town, Southwestern Ethiopia. Journal of Food and Nutrition Sciences.

Vol. 5, No. 2, 2017, pp. 44-50. doi: 10.11648/j.jfns.20170502.14

Received: April 5, 2016; Accepted: March 1, 2017; Published: March 18, 2017

\begin{abstract}
Nutritional status is the major factor that can affect academic performance of school children. The main aim of this study was to determine the association between iodine deficiency disorder and academic performance among school age children. Both community \& school based cross sectional survey was conducted from October 1-30, 2010. A total of 1254 students, aged 6-12 years, were selected from five primary schools using systematic random sampling method. Goiter examinations and urine iodine test was done to diagnose goiter. Spot urine samples were collected to determine median urinary iodine level and anthropometric measurements were done. In this study, 1,254 children were included; 674 (53.7\%) were males. Average academic score of students for both sexes was $71.13 \%$. Majority of students $349(71.2 \%)$ who had goiter scored below average $(\mathrm{p}=0.01)$. High median urinary iodine level $[\mathrm{AOR}=0.38 ; 95 \% \mathrm{CI}(0.190,0.489)]$; high height-for-age $\mathrm{z}$ score $[\mathrm{AOR}=5.023 ; 95 \% \mathrm{CI}(3.317,7.607)]$; and high weight-for-age $\mathrm{z}$-score [AOR=3.214; 95\% CI $(2.091,4.941])$ were significantly associated with good school performance. Iodine deficiency disorder is a significant health problem among schoolchildren in the study area. Strengthening salt iodization program is a preventive measure.
\end{abstract}

Keywords: Goiter, Iodine Deficiency, Academic Performance, Urinary Iodine

\section{Introduction}

Iodine is an essential micronutrient for the regulation of physical growth and neural development. Insufficient iodine level in the blood leads to poor production of thyroid hormones. The most visible effect of Iodine Deficiency Disorder (IDD) is goiter, resulting from either low iodine intake or ingestion of goitrogens [1].

Globally more than two billion people are estimated to be at risk of IDD and 260 million people in Africa are at risk and 150,000 are affected by goiter. The most recent national survey of IDD conducted by Ethiopian Health and Nutrition Research Institute (EHNRI, 2005) indicated that a high prevalence of goiter rate as nearly as $40 \%$ in school age children and 36\% in mothers [2].

Iodine deficiency in the soil affects all forms of plant life and crops grown on iodine depleted soil will have low iodine content. Thus, populations who rely on subsistence agriculture are more likely to be exposed to iodine deficiency if the soil's iodine content is low [3].

Thyroid hormones play an important role in cellular metabolism and early growth and development of most organs, especially of the brain. Consequently, deficiency in iodine and/or in thyroid hormones occurring during this critical period of life will result in slowing down of metabolic activities and irreversible alterations of brain development [4].

Poor academic achievement has been a major area of concern for educators, parents, and students. Poor nutritional 
status among school children has significant adverse effects on school progress. There is a direct relationship between prevalence of malnutrition and educational wastage. Malnourished children have difficulties to master school educational materials and have high chances of repeating grades and dropping out early from school [5].

Universal salt iodization program as a preventive means is not strictly controlled in Ethiopia. In 2003 a remarkable progress was made to increase access to iodized salt by training salt producing companies and quality control laboratory technicians. The problem has persisted yet. The main objective of this study is to determine the association between iodine deficiency disorder and academic performance among school age children.

\section{Materials and Methods}

\subsection{Study Design and Area}

Cross sectional study design was conducted among school age children in Jimma town from October 1-30, 2010. Samples of 1254 children were selected from five primary schools (Hirmata, Kittoo, Jiren, Mandara \& Ginjo) by systematic random sampling method. Sample size was calculated using single population proportion formula by taking overall IDD prevalence of $53.5 \%$ [6], 95\% confidence interval \& 5\% non response rate.

A pre-tested structured questionnaire was used for data collection. Academic records were reviewed, physical examination for goiter was done, urinary iodine test and anthropometric measurements were conducted. School document review was done to gather information about the student's grade report and grade averages. School performance during the previous year was obtained from school records. Good school performance was defined as an overall average grade of $>71.13 \%$ during the previous academic year.

Iodine Deficiency Disorder (IDD) manifested as goiter was palpated and graded by physicians using standard procedures as per the criteria of WHO/UNICEF/ICCIDD. According to these criteria, goiter was graded as follows: Grade zero: no palpable or visible goiter; Grade 1: a goiter that is palpable but not visible when the neck is in the normal position and Grade 2: A swelling in the neck, that is visible when the neck is in a normal position [7].

\subsection{Ethics Approval}

Ethical clearance for the study was obtained from the ethical review board of Jimma University, College of Public Health and Medical Sciences. The objective of the study and advantages obtained from the study was clarified to the parents or guardians of the children and written informed consent was obtained from the parents or guardians of the children to undertake the study. Confidentiality was maintained.

\subsection{Data Collection}

About $5 \mathrm{ml}$ of spot urine samples were collected from sampled students in a properly labeled and sterile urine cups. These cups were immediately transferred to the thermo cool box containing ice bags and were transported to the laboratory. The samples were kept at $4{ }^{\circ} \mathrm{C}$ in a refrigerator with all precautions until analysis. Analysis of urinary iodine was done using spectrophotometer based on ammonium persulfate method, as suggested and approved by WHO/UNICIEF/ICCIDD [3]. This involves the spectrophotometric analysis of a reaction media which utilizes iodine as a catalyst. During this reaction cerric ammonium sulfate (yellow in color), one of the reactant is reduced to cerrous (colorless) form. The absorbance value (optical density, OD); at $405 \mathrm{~nm}$ is inversely proportional to the iodine content of the sample, i.e. the more the absorbance the less is the iodine content. The absorbance value can be used for the determination of the actual iodine concentration using a standard graph prepared by using a range of standard $\mathrm{KIO}_{3}$ solutions [3].

WHO/UNICEF/ICCIDD recommended that, the iodine deficiency level should be determined in a given community by measuring the level of iodine excretion in the urine. The urinary iodine excretion (UIE) values are compared with established cutoff points to assess the degree of iodine deficiency. Median UIE values less than $20 \mu \mathrm{g} / \mathrm{L}$ indicate severe iodine deficiency, values between 20-49.9 $\mu \mathrm{g} / \mathrm{L}$ indicate moderate deficiency, values between 50-99.9 $\mu \mathrm{g} / \mathrm{L}$ indicate mild iodine deficiency, and values between 100$199.9 \mu \mathrm{g} / \mathrm{L}$ indicate adequate iodine level [3].

Height was measured to the nearest 0.1 centimeters $(\mathrm{cm})$ on barefoot, participants stood upright against a mounted portable stadiometer (Charder HM200P Portstad). Weight was measured to the nearest 0.1 kilogram $(\mathrm{kg})$, participants lightly dressed (underwear and T-shirt) using a portable digital weighing scale (Tanita HA-623). Anthro plus 3.2.2 was used to calculate the nutritional indices, including weight-for-age percentiles and height-for-age percentiles.

\subsection{Data Analysis}

Data analysis was done using SPSS version 20 software and association between dependent \& independent variables were examined. Chi-Square test analysis was done to see the relationship between school performance and other independent variables. Multiple logistic regression analysis was done to see the effect of all confounding variables on the outcome variable. $P$ value $<0.05$ was considered significant.

In order to analyze the nutritional status of the student, their weight and height was converted into z-scores based on the National Center for Health Statistics (NCHS) reference population recommended by the WHO. Thus, those below -2 standard deviations of the NCHS median reference for height-for-age and weight-for-age were defined as stunted and underweight respectively [8].

A low height-for-age z-score (stunting) indicates that slow physical growth since the birth date. This is usually due to repeated episodes of poor nutrition and/or episodes of diarrhea and other illnesses. It is a cumulative indicator of past episodes of malnutrition. A low weight-for-age z-score 
(underweight) reflects both stunting and wasting or a low weight-for-height z-score [8].

\section{Results}

Amongst 7756 school age children in the five primary schools of Jimma town, a sample 1254 students were interviewed and examined, of whom 674 (53.7\%) were males and $580(46.3 \%)$ were females. The majority of students, 760 $(60.6 \%)$ were in the age range of 6-9 years.

The prevalence of goiter among the children was $39.1 \%$, out of which $21.3 \%$ had palpable (Grade-1) and 17.8\% had visible (Grade-2) goiter. The prevalence of goiter was significantly higher among females $21.4 \%$ than in males $17.7 \%(\mathrm{p}=0.001)$ as shown in table 1 .

Academic Performance of school children: Average score of students for both sexes was $71.13 \%$. Regarding the educational status of the father, most of the students 286 $(60.3 \%)$ who scored below average had illiterate fathers.

As shown on table 1, high goiter prevalence 379 (77.3\%) was observed in children whose parent's monthly income is < 2000 Ethiopian birr $(\mathrm{p}=0.00)$.

Based on possession index, most of the students who scored above average had the access to toys 494 (75.7\%), television 551 (68.7\%), and radio $517(72.6 \%)$.

Assessment of urinary iodine concentration (UIC) showed that, $74.9 \%$ of children had UIC $<100 \mu \mathrm{g} / \mathrm{L}$, which is an indicator of iodine deficiency. Among these, 9.6\% were severely iodine deficient, $33.7 \%$ were moderately iodine deficient, and $31.6 \%$ were mildly iodine deficient based on the classification recommended by WHO. Children who had adequate iodine concentration (UIC between $100 \mu \mathrm{g} / \mathrm{L}$ and $199.9 \mu \mathrm{g} / \mathrm{L})$ were only $25.1 \%$ and the median UIC was $51 \mu \mathrm{g} / \mathrm{L}$.

Children who were moderately iodine deficient had a higher prevalence of goiter $(39.6 \%)$ than those who had adequate iodine concentration $(14.1 \%)$. In this study, UIC was significantly correlated with prevalence of goiter $(\mathrm{p}=0.02)$.

Majority of the students $524(68.6 \%)$ with median urinary iodine level $<51 \mu \mathrm{g} / \mathrm{L}$ scored below average academic performance compared to students with median urinary iodine level $>51 \mu \mathrm{g} / \mathrm{L}$. (Table 3)

Significantly higher number of students 349 (73.6\%) who had goiter scored below average academic performance compared to those without goiter $125(26.4 \%) \quad(p=0.00)$. Students with low height for age z-score $362(70.4 \%)$ and low weight for age $z$-score 356 (66.5\%) had low academic performance compared to students with high height for age $\mathrm{z}$ score $112(15.1 \%)$ and high weight for age $z$-score 118 (16.4\%). (Table 5)

Factors associated with goiter: Majority of the children $184(37.6 \%)$ consume cabbage every day. Significantly higher rate of goiter $(\mathrm{p}=0.001)$ was observed among children who consumed cabbage everyday $184(37.6 \%)$ than those who never consumed cabbage $22(4.5 \%)$.

Variables which were identified to have significant association (at significance level of 0.05 ) with goiter in the
Chi-Square test analysis were entered into stepwise forward multivariate regression. In multivariate logistic regression model, sex $[\mathrm{AOR}=4.84,95 \% \mathrm{CI} \quad(3.25-9.86)]$, and consumption of common goitrogenic foods like cabbage twice in a week $[\mathrm{AOR}=8.3 ; 95 \% \mathrm{CI}(6.32-12.7]$ had an independent association with goiter. (Table 4)

Factors associated with academic performance: The effects of different variables were tested using multiple logistic regression analysis so as to determine the expected predictors of academic performance.

Children whose fathers monthly income $>2000$ Birr [AOR $=5.743 ; 95 \% \mathrm{CI}$ 4.411-7.477)], absence of goiter $[\mathrm{AOR}=4.368 ; 95 \% \mathrm{CI}=2.974-6.414)]$, greater median urinary iodine level $[\mathrm{AOR}=0.38 ; 95 \% \mathrm{CI}=0.190-0.489)]$, high height for age $z$-score $[\mathrm{AOR}=5.023 ; 95 \% \mathrm{CI}(3.317-7.607)]$, and high weight for age $\mathrm{z}$-score $[\mathrm{AOR}=3.214 ; 95 \% \mathrm{CI}=2.091$ 4.941)] were associated with high school performance, (Table 5).

\section{Discussion}

Nutritional status is a major factor that can affect academic performance of schoolchildren. The scientific evidence shows that malnutrition in infants and children is a risk factor in the formal educational system [1]. In the studied area, the total goiter prevalence was $39.1 \%$ indicating that IDD is a severe public health problem. This result is in agreement with earlier reports given by Chernet et al, who reported the overall goiter rate in Ethiopia to be 39.9\% [9].

The prevalence of goiter was significantly higher among females $21.4 \%$ than in males $17.7 \%$. This result is in agreement with the study reported by Yinebeb et al, [10]. Females are being more vulnerable to goiter than males because of such physiological reasons as puberty occurs 2 years earlier than males. Iodine demand is increased during pubertal period.

High goiter rate was recorded among children from low income family. The higher goiter prevalence among low income category could be associated with poor nutritional intake, less consumption of meat, use of non iodized salt and lack of medical attention. This suggests that living standard is having a direct relation with iodine nutritional status and thereby with high goiter prevalence [10].

A direct correlation was established between the frequency of cabbage intake and goiter prevalence. Those who consume cabbage everyday were 11.5 times more vulnerable to goiter than those who never consume. [AOR 11.5, 95\% CI (7.0118.20)]. This result is in consistent with a report obtained from Ethiopia [11]. This is because; goitrogens contain thiocyanate and isothiocyanate that inhibit the uptake of iodine to the thyroid follicular cells and also blocks the thyroid peroxidase enzyme. In the presence of goitrogen iodination of thyroglobulin protein will be affected, inducing in poor thyroxine production and enlargement of the thyroid.

In the present study, the presence of goiter in school children was independently associated with school performance. Children who had goiter had higher odds of 
getting below average score in their school grade compared to those who did not have goiter. Other studies conducted in Malaysia [12] and Tanzania [13] revealed a similar negative effect of iodine deficiency disorder on the academic performance of schoolchildren.

A direct relationship was observed between anthropometric measurement and academic performance. School children having greater than $-2 \mathrm{SD}$ of height for age and weight for age $\mathrm{z}$ score were scored good school performance. Height and weight have a significant association with learning, suggesting the importance of nutrition in the education system [14]. Other studies have also investigated the associations between height-for-age and school achievement [15]. This may be because of the hypothesis that under nutrition causes poor motor development and subsequent low activity levels. It also causes apathy and lack of interest in the environment. Another possible mechanism is that under nutrition could have a direct effect on the children's central nervous system.

Median urinary iodine level is a valuable indicator of the iodine nutritional status of the entire population. In the present study, the median urinary iodine concentration is $51 \mu \mathrm{g} / \mathrm{L}$, which is below $100 \mu \mathrm{g} / \mathrm{L}$ and this further indicates the presence of iodine deficiency disorder in the studied population. Children with above median urinary iodine level have good school performance compared to students with less median urinary iodine [16].

\section{Conclusions}

The present study revealed that iodine deficiency goiter is a significant health problem among school age children in the study area. Hypothyroidism due to iodine deficiency reduces physical growth and retards learning capacity. Strengthening salt iodization programs is strongly recommended as a preventive measure.

\section{Acknowledgements}

We express our sincere gratitude to Jimma University for its financial support. We also would like to acknowledge respondents and data collectors.

Table 1. Sociodemographic \& Socioeconomic Characteristics and Goiter Status of School Children, $n=1254$.

\begin{tabular}{|c|c|c|c|c|}
\hline \multirow{2}{*}{ Variables } & \multicolumn{4}{|l|}{ Goiter status } \\
\hline & Normal n (\%) & Present n (\%) & Total n (\%) & p-value \\
\hline \multicolumn{5}{|l|}{ Sex } \\
\hline Male & $452(59.2)$ & $222(45.3)$ & $674(53.7)$ & \multirow[t]{2}{*}{0.05} \\
\hline Female & $312(40.8)$ & $268(54.7)$ & $580(46.3)$ & \\
\hline \multicolumn{5}{|l|}{ Age (year) } \\
\hline $6-9$ & 487 (63.7) & $273(55.7)$ & $760(60.6)$ & \multirow[t]{2}{*}{0.25} \\
\hline $10-12$ & $277(36.3)$ & $217(44.3)$ & $494(39.4)$ & \\
\hline \multicolumn{5}{|c|}{ Frequency of cabbage intake } \\
\hline Everyday & $146(19.1)$ & $184(37.6)$ & $330(26.3)$ & \multirow{5}{*}{0.01} \\
\hline $3 \mathrm{x} /$ week & $68(8.9)$ & $62(12.7)$ & $130(10.4)$ & \\
\hline $2 \mathrm{x} /$ week & $153(20.0)$ & $129(26.3)$ & $282(22.5)$ & \\
\hline 1x/week & $195(25.5)$ & $93(19.0)$ & $288(23.0)$ & \\
\hline Never & $202(26.4)$ & $22(4.5)$ & $224(17.9)$ & \\
\hline \multicolumn{5}{|c|}{ Monthly income (ETB) } \\
\hline$<2000$ & $306(40.1)$ & $379(77.3)$ & $685(54.6)$ & \multirow[t]{2}{*}{0.00} \\
\hline$\geq 2000$ & $458(59.9)$ & $111(22.7)$ & $569(45.4)$ & \\
\hline \multicolumn{5}{|c|}{ Literacy status of the father } \\
\hline Illiterate & $440(57.6)$ & $270(55.1)$ & $710(56.6)$ & \multirow[t]{2}{*}{0.21} \\
\hline Literate & $324(42.4)$ & $220(44.9)$ & $544(43.4)$ & \\
\hline \multicolumn{5}{|c|}{ Literacy status of the mother } \\
\hline Illiterate & $506(66.2)$ & $323(65.9)$ & $829(66.1)$ & \multirow[t]{2}{*}{0.47} \\
\hline Literate & $258(33.8)$ & $167(34.1)$ & $425(33.9)$ & \\
\hline
\end{tabular}

Current exchange rate, $\$ 1.00$ USD $=20.70$ ETB, Ethiopian Birr

Table 2. Association Between Socio Demographic and Socio Economic Variables and Academic Performance of School Children, $n=1254$.

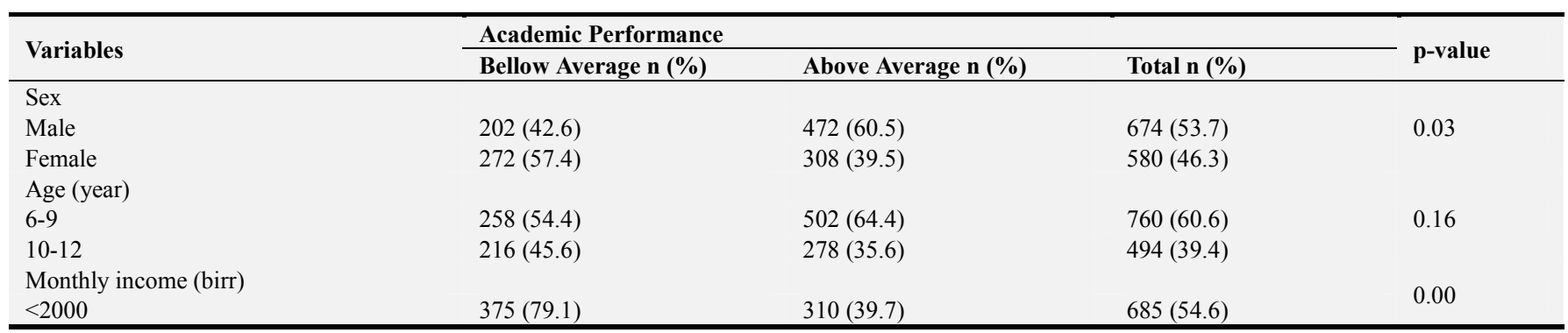




\begin{tabular}{|c|c|c|c|c|}
\hline \multirow{2}{*}{ Variables } & \multicolumn{3}{|l|}{ Academic Performance } & \multirow{3}{*}{ p-value } \\
\hline & Bellow Average n (\%) & Above Average n (\%) & Total n (\%) & \\
\hline$\geq 2000$ & $99(20.9)$ & $470(60.3)$ & $569(45.4)$ & \\
\hline \multicolumn{5}{|c|}{ Literacy status of the father } \\
\hline Illiterate & $286(60.3)$ & $424(54.4)$ & $710(56.6)$ & \multirow[t]{2}{*}{0.02} \\
\hline Literate & $188(39.7)$ & $356(45.6)$ & $544(43.4)$ & \\
\hline \multicolumn{5}{|c|}{ Literacy status of the mother } \\
\hline Illiterate & $316(66.7)$ & $513(65.8)$ & $829(66.1)$ & \multirow[t]{2}{*}{0.39} \\
\hline Literate & $158(33.3)$ & $267(34.2)$ & $425(33.9)$ & \\
\hline \multicolumn{5}{|c|}{ Availability of toys } \\
\hline Yes & $159(33.5)$ & $494(63.3)$ & $653(52.1)$ & \multirow[t]{2}{*}{0.03} \\
\hline No & $315(66.5)$ & $286(36.7)$ & $601(47.9)$ & \\
\hline \multicolumn{5}{|c|}{ Availability of television } \\
\hline Yes & $251(53.0)$ & $551(70.6)$ & $802(64.0)$ & \multirow[t]{2}{*}{0.02} \\
\hline No & $223(47.0)$ & $229(29.4)$ & $452(36)$ & \\
\hline \multicolumn{5}{|c|}{ Availability of radio } \\
\hline Yes & $195(41.1)$ & $517(66.3)$ & $712(56.8)$ & \multirow[t]{2}{*}{0.04} \\
\hline No & $279(58.9)$ & $263(33.7)$ & $542(43.2)$ & \\
\hline \multicolumn{5}{|c|}{ House ownership } \\
\hline Our own & $222(46.8)$ & $564(72.3)$ & $786(62.7)$ & \multirow{3}{*}{0.39} \\
\hline Rent & $227(47.9)$ & $189(24.2)$ & $416(33.2)$ & \\
\hline Don't know & $25(5.3)$ & $27(3.5)$ & $52(4.1)$ & \\
\hline
\end{tabular}

Current exchange rate, $\$ 1.00$ USD $=20.70$ ETB, Ethiopian Birr

Table 3. Association Between Urinary Iodine Excretion Level and Academic Performance of School Children, $n=1254$.

\begin{tabular}{|c|c|c|c|c|}
\hline \multirow{2}{*}{ Urinary iodine excretion $(\mu \mathrm{g} / \mathrm{L})$} & \multicolumn{4}{|l|}{ Goiter status } \\
\hline & Normal n (\%) & Goitrous n (\%) & Total n (\%) & $P$ value \\
\hline$<20$ & $69(9.0)$ & $51(10.4)$ & $120(9.6)$ & \multirow[t]{6}{*}{0.02} \\
\hline $20-49.9$ & $229(30.0)$ & $194(39.6)$ & $423(33.7)$ & \\
\hline $50-99.9$ & $220(28.8)$ & $176(35.9)$ & 396 (31.6) & \\
\hline $100-199.9$ & $246(32.2)$ & $69(14.1)$ & $315(25.1)$ & \\
\hline \multirow{2}{*}{ Median urinary iodine $(\mathrm{MUI})=51 \mu \mathrm{g} / \mathrm{L}$} & \multicolumn{3}{|l|}{ Academic performance } & \\
\hline & Bellow average $\mathrm{n}(\%)$ & Above average $\mathrm{n}(\%)$ & Total $n(\%) P$ value & \\
\hline$<51 \mu \mathrm{g} / \mathrm{L}$ & $524(68.6)$ & $66(13.5)$ & $590(47.0)$ & \multirow{2}{*}{0.05} \\
\hline$\geq 51 \mu \mathrm{g} / \mathrm{L}$ & $240(31.4)$ & $424(86.5)$ & $664(53.0)$ & \\
\hline \multicolumn{4}{|l|}{ Goiter status } & \multirow{3}{*}{0.01} \\
\hline Normal & $125(26.4)$ & $639(81.9)$ & $764(60.9)$ & \\
\hline Goitrous & 349 (73.6) & $141(18.1)$ & $490(39.1)$ & \\
\hline
\end{tabular}

Table 4. Predictors of Goiter Among School Children, $n=1254$.

\begin{tabular}{|c|c|c|c|}
\hline \multirow{2}{*}{ Variables } & \multicolumn{2}{|l|}{ Goiter status } & \multirow{2}{*}{ AOR 95\% CI } \\
\hline & Normal n (\%) & Present n (\%) & \\
\hline \multicolumn{4}{|l|}{ Sex } \\
\hline Male & $452(59.2)$ & $222(45.3)$ & 1.00 \\
\hline Female & $312(40.8)$ & $268(54.7)$ & $4.84(3.25-9.86)$ \\
\hline \multicolumn{4}{|c|}{ Monthly income (ETB) } \\
\hline$<2000$ & $306(40.1)$ & $379(77.3)$ & $0.196(0.151-0.253)$ \\
\hline$\geq 2000$ & 458 (59.9) & $111(22.7)$ & 1.00 \\
\hline \multicolumn{4}{|l|}{ Age (year) } \\
\hline $6-9$ & 487 (63.7) & $273(55.7)$ & $0.79(0.69-3.59)$ \\
\hline $10-12$ & $277(36.3)$ & $217(44.3)$ & 1.00 \\
\hline \multicolumn{4}{|c|}{ Frequency of cabbage intake } \\
\hline Everyday & $146(19.1)$ & $184(37.6)$ & 11.5 (7.01-18.20)* \\
\hline $3 \mathrm{x} /$ week & $68(8.9)$ & $62(12.7)$ & $7.7(4.7-14.63)$ \\
\hline $2 \mathrm{x} /$ week & $153(20.0)$ & $129(26.3)$ & $83(6.32-12.7)$ \\
\hline $1 \mathrm{x} /$ week & $195(25.5)$ & $93(19.0)$ & $0.9(0.71-1.96)$ \\
\hline Never & $202(26.4)$ & $22(4.5)$ & 1.00 \\
\hline \multicolumn{4}{|c|}{ MUI $(51 \mu \mathrm{g} / \mathrm{L})$} \\
\hline$<51 \mu \mathrm{g} / \mathrm{L}$ & $240(31.4)$ & $424(86.5)$ & $14.02(10.38,18.95)^{*}$ \\
\hline$>51 \mu \mathrm{g} / \mathrm{L}$ & $524(68.6)$ & $66(13.5)$ & 1.00 \\
\hline
\end{tabular}

*Significance at $\mathrm{p}<0.05$, Current exchange rate, $\$ 1.00 \mathrm{USD}=20.70 \mathrm{ETB}$, Ethiopian Birr 
Table 5. Predictors of Academic Performance Among School Children, $n=1254$.

\begin{tabular}{|c|c|c|c|}
\hline \multirow{2}{*}{ Variables } & \multicolumn{2}{|c|}{ Academic Performance } & \multirow{2}{*}{ AOR 95\% CI } \\
\hline & Bellow mean n (\%) & Above mean n (\%) & \\
\hline \multicolumn{4}{|c|}{, } \\
\hline Male & $202(30.0)$ & $472(70.0)$ & $1.844(0.255-2.710)$ \\
\hline Female & $272(46.9)$ & $308(53.1)$ & 1.00 \\
\hline \multicolumn{4}{|c|}{ Monthly income (ETB) } \\
\hline$<2000$ & $375(79.1)$ & $310(39.7)$ & 1.00 \\
\hline$\geq 2000$ & $99(20.9)$ & $470(60.3)$ & $5.743(4.411-7.477)^{*}$ \\
\hline \multicolumn{4}{|c|}{ Literacy status of the father } \\
\hline Illiterate & $286(60.3)$ & $424(54.4)$ & $0.370(0.242-1.594) 1.00$ \\
\hline Literate & $188(39.7$ & $356(45.6)$ & \\
\hline \multicolumn{4}{|c|}{ Availability of Toys } \\
\hline Yes & $159(24.3$ & $494(75.7)$ & $1.420(0.938-2.176)$ \\
\hline No & $315(52.4$ & $286(47.6)$ & 1.00 \\
\hline \multicolumn{4}{|c|}{ Availability of Television } \\
\hline Yes & $251(31.3)$ & $551(68.7)$ & $0.872(0.551-1.380)$ \\
\hline No & $223(49.3$ & $229(50.7)$ & 1.00 \\
\hline \multicolumn{4}{|c|}{ Availability of Radio } \\
\hline Yes & $195(27.4)$ & $517(72.6)$ & $2.637(0.767-3.935)$ \\
\hline No & $279(51.5$ & $263(48.5)$ & 1.00 \\
\hline \multicolumn{4}{|c|}{ Going to bed hungry } \\
\hline Yes & $256(44.9)$ & $314(55.1)$ & $0.671(0.449-1.002)$ \\
\hline No & $218(31.9$ & $466(68.1)$ & 1.00 \\
\hline \multicolumn{4}{|l|}{ Goiter status } \\
\hline Normal & $125(16.4)$ & $639(83.6)$ & $4.368(2.974-6.414)^{*}$ \\
\hline Goitrous & $349(71.2$ & $141(28.8)$ & 1.00 \\
\hline \multicolumn{4}{|c|}{ Median urine iodine level $(51 \mu \mathrm{g} / \mathrm{l})$} \\
\hline Bellow mean & $408(61.4)$ & $256(38.6)$ & 1.00 \\
\hline Above mean & $66(11.2)$ & $524(88.8)$ & $0.38(0.190-0.489)^{*}$ \\
\hline \multicolumn{4}{|c|}{ Height for age $Z$ score } \\
\hline High ( $>-2$ SD) & $112(15.1)$ & $628(84.9)$ & $5.023(3.317-7.607)^{*}$ \\
\hline Low $(<-2 \mathrm{SD})$ & $362(70.4$ & $152(29.6)$ & 1.00 \\
\hline \multicolumn{4}{|c|}{ Weight for age $\mathrm{Z}$ score } \\
\hline High (>-2 SD) & $118(16.4)$ & $601(83.6)$ & $3.214(2.091-4.941)^{*}$ \\
\hline Low $(<-2$ SD) & $362(70.4$ & $152(29.6)$ & 1.00 \\
\hline \multicolumn{4}{|c|}{ Families encourage education } \\
\hline Yes & $239(27)$ & $645(73)$ & $1.30(0.837-2.930)$ \\
\hline No & $235(65.5$ & $135(36.5)$ & 1.00 \\
\hline \multicolumn{4}{|c|}{ Shortage of educational material } \\
\hline Yes & $287(47.2)$ & $393(57.8)$ & $0.17(0.024-1.394)$ \\
\hline No & $187(32.6$ & $387(67.4)$ & 1.00 \\
\hline
\end{tabular}

*Significance at $\mathrm{p}<0.05$, Current exchange rate, $\$ 1.00 \mathrm{USD}=20.70 \mathrm{ETB}$, Ethiopian Birr

\section{References}

[1] Federal Ministry of Health, Ethiopian National Guidelines for Control and Prevention of Micronutrient Deficiencies, June 2004.

[2] Anwar Y., Sisay Y., Desalegn T., Yifokir T., Takele T., Taddis B. Iodine Deficiency Disorders For the Ethiopian Health Center Team. University of Gondar; 2007.

[3] WHO/ICCIDD/UNICEF, Assessment of the iodine deficiency disorders and monitoring their elimination. Geneva: World Health Organization, 2007.

[4] Taurog A. Hormone synthesis and thyroid iodine metabolism. In: Braverman LE, Utiger RD, editors. The Thyroid: A Fundamental and Clinical Text. 8th ed. Philadelphia, PA: JB Lippincott Publishing, 2000. pp. 51-97.

[5] Alicia P., Laura A., Rosa I., Clementina M., Homero M. Iodine deficiency and its association with intelligence quotient in school children from Colima, Mexico. Public health nutrition, 2008; 11 (7): 690-8.

[6] Cherinet A., Kelbessa U. Determinants of iodine deficiency in school children in different regions of Ethiopia. East African Medical Journal, 2000; 77 (3): 133-37.

[7] World Health Organization, Assessment of iodine deficiency disorders and monitoring their elimination. A guide for program managers. Geneva, 2001.

[8] Akor F., Okolo S., Okolo A. Nutritional Status of Newly Enrolled Primary School Children. Pakistan Journal of Nutrition, 2010; 9: 1166-1170.

[9] Chernet A., Berhane Y., Akalu G., Ethan Z., Ersumo T. Prevalence of goiter in children 6 to 12 years of age in Ethiopia. Food and Nutrition Bulletin, 2007; 28: 391.

[10] Yinebeb M., Andualem M., Rajesh PN., Getenet B. Prevalence and Severity of Iodine Deficiency Disorder Among Children 6-12 Years of Age in Shebe Senbo District, Jimma Zone, Southwest Ethiopia. Ethiop J Health Sci, 2012; 22: 196-204. 
[11] Cherinet A. Yermane B. The goitre rate, its association with reproductive failure, and the knowledge of iodine deficiency disorders (IDD) among women in Ethiopia: cross-section community based study. BMC Public Health, 2007; 7: 316-16.

[12] Zaleha M., Iskandar Z., Khalid, Osman A. Effect of iodized oil sopplementation on thyroid hormone level and mental performance among Orang Asli school children and pregnant mothers in an endemic goiter area in peninsular Malaysia. Asia Pacific J Clin Nutr, 2000; 9: 274-81.

[13] Erica M., Robles O., Torero M. The cognitive link between Geography and Development. Iodine deficiency and schooling attainment in Tanzania. Working paper 2008.
[14] Hedwig A., Joyce K., Silas O., Marian K., Thorkild T. Height, weight, body mass index and learning achievement. National Institute of Nutrition and Sea Food Research, 2008; 3: 1-8.

[15] Darci N., Ana M., Ana C. Determinants of cognitive function in childhood: A cohort study in a middle income context. BMC Public Health, 2008, 8: 202.

[16] Tafere G., Nega T., Afework M., Yewelsew A., Hambidge K. M., Stoecker B. J. Lack of Dietary Sources of Iodine and the Prevalence of Iodine Deficiency in Rural Women from Sidama Zone, Southern Ethiopia. AJFAND, 2013; 13: 5. 